Cahiers de recherches médiévales

La Figure de Jules César au Moyen Âge et à la Renaissance (II)

\title{
The Wedding Reception
}

Rewriting the Ideological Challenge in the prose Cligès 1454)

Rebecca Dixon

\section{(2) OpenEdition}

\section{Journals}

Electronic version

URL: https://journals.openedition.org/crm/2588

DOI: $10.4000 / \mathrm{crm} .2588$

ISSN: 1955-2424

Publisher

Honoré Champion

Printed version

Date of publication: 30 June 2007

Number of pages: $315-326$

ISSN: $1272-9752$

Electronic reference

Rebecca Dixon, "The Wedding Reception", Cahiers de recherches médiévales [Online], 14 spécial | 2007, Online since 30 June 2010, connection on 15 December 2022. URL: http://journals.openedition.org/ crm/2588; DOI: https://doi.org/10.4000/crm.2588 


\section{RM}

\section{The Wedding Reception : Rewriting the Ideological Challenge in the prose Cligès (1454)}

Central to the literary output of the mid-fifteenth-century Burgundian court under Philip the Good was the phenomenon of the mise en prose, a process involving the rewriting of earlier source-texts, always Francophone and generally verse, in more legible Middle French prose for the duke and his intimates. ${ }^{1}$ Achieving this legibility depended not simply on a remanieur's ability to translate («translatter») the retrograde and incomprehensible language of his source, but also on the extent to which he was able appropriately to rework the verse avatar for consumption at court, to «transmuer de rime en prose» the earlier text in ways which made it acceptable to a new audience. ${ }^{2}$ The production of a mise en prose becomes both a textual and a meta-textual interpretative exercise, a programme of intralingual translation persuasively glossed by Jane Taylor as acculturation: «a process whereby the socioculturally unfamiliar is recast in familiar terms, so that the reader can understand systems and phenomena in a source text corresponding to his own ideologies, preconceptions and behaviour-patterns $\gg .^{3}$ As Taylor suggests, sometimes these «systems and phenomena» involve features in the source-text which would prove locally confusing to an unattuned Burgundian readership; often, though, the « unfamiliar» and unpalatable aspect of the avatar lies in its presentation of an alterity that is morally, rather than straightforwardly culturally, troubling. Ideological challenges are thrown down for the remanieur by his source; and his task inheres in developing strategies to contain and contend with these challenges in his reworking.

The present study proposes the punctual examination of one such narrative and hermeneutic strategy in a Burgundian text, the mise en prose of Chrétien de Troyes's Cligès. ${ }^{4}$ Whether in its verse or prose version, the story of the Cligès falls into two parts, ${ }^{5}$ the first recounting the arrival at the Arthurian court of Alixandre, a young nobleman from Constantinople, and his subsequent vexed falling in love with

${ }^{1} \mathrm{G}$. Doutrepont, Les mises en prose des épopées et des romans chevaleresques du XIV au XVI siècle, Brussels, 1939.

${ }^{2}$ L'Histoire de Erec en prose, roman du XV $V^{e}$ siècle, ed. M. Colombo Timelli, Geneva, 2000, p.101. On the distinction between the usage of «translatter» (to translate) and «transmuer» (to rework) in the mise en prose, see R. E. F. Straub's comments on their prologues in David Aubert, escripvain et clerc, Amsterdam and Atlanta, 1995.

3 J. H. M. Taylor, "The Significance of the Insignificant: Reading Reception in the Burgundian Erec and Cligès », Fifteenth-Century Studies 24, 1998, p. 183-97 ; p. 183.

${ }^{4}$ Le Livre de Alixandre Empereur de Constantinoble et de Cligés son Fils. Roman en prose du $X V^{e}$ siècle, ed. M. Colombo Timelli, Geneva, 2004. All references to the text will appear in the body of the article.

${ }^{5}$ The bi-partite structure of the text is reflected in the title of the prose (see $n .4$ above) as it is not in the verse.

Cahiers de Recherches Médiévales, 14spé, 2007 
the proud Soredamours, and the second following the chivalric and amorous trajectory of their son, Cligès, as he falls in love with Fenice, who happens to be betrothed to his uncle, Alix. Both parts of the text discuss in different ways the rightness of love, and the pursuit of legitimate love ; and both parts are fraught with interpretative problems, and questions left unresolved by Chrétien, to which the remanieur must respond as he devises his reworking. Though disingenuously decrying his «engin...non suffisant ad ce» (p. 65) in the prologue, in rethinking and rewriting the Cligès for his Burgundian patron the remanieur is revealed to be a subtle and suggestive reader of his verse avatar. Moments of crisis evinced in Chrétien's version are articulated and levelled by the Burgundian through a stunning, and specific, «deletion of alterity $»^{6}$ focused on the ethical and exegetical challenge of the perceived incest in Cligès and Fenice's relationship.

In Incest and the Medieval Imagination, Elizabeth Archibald discusses the various levels of consanguinity acceptable under medieval law when relatives of any degree were minded to marry. "There is little sense in these [legal] texts», she claims, « of a hierarchy of forms of incest in which partners within the nuclear family are differentiated from more distant relatives, or from spiritual kin $»{ }^{7}$ So while the union between Cligès and Fenice might appear to be legitimate because the pair are not bound by blood - and also because Fenice's marriage to Alix is technically unconsummated -, the spiritual kinship between aunt and nephew is enough to suggest that, for readers of Chrétien's text as for the fifteenth-century remanieur, «the shadow of incest must have hung over the story $\gg .{ }^{8}$ And it is this shadow cast across the Cligès that challenges the Burgundian author, prompts him to «write out» this threatening aspect of the source, to bring it into line with appropriate ideologies for his courtly audience. To do this the remanieur engages creatively with an unremarkableseeming aspect of Chrétien's work - the Champenois poet's deployment of the personification Amours in the first half of his text - and presses it into the service of new (and legitimising) coherences in his mise en prose.

Maria Colombo Timelli mentions in her introduction to the Cligès personifications of abstract notions such as Raison, Adventure, Mort, and Amours being used to «projeter à l'extérieur les sentiments mêmes des personnages» (p. 38) in the prose

\footnotetext{
${ }^{6}$ The term is Taylor's, op. cit., p. 191.

${ }^{7}$ E. Archibald, Incest and the Medieval Imagination, Oxford, 2001, p. 38, emphasis added. See also L. Dunton-Downer, «The Horror of Culture: East-West Incest in Chrétien de Troyes's Cligés », New Literary History 28.2, 1997, p. 367-381. For other examples of incest in the mise en prose needing to be contained and written out see La Belle Hélène de Constantinople and La Manekine, discussed in R. Dixon, «Une Moult Estrange Chose : Encounters with the Alien in Burgundian Prose Literature c.1445 - 1468 » (unpublished Ph.D thesis, University of Durham 2006), especially Chapter Five.

${ }^{8}$ Archibald, op. cit., p. 223. Incest law of course developed throughout the Middle Ages ; but as Archibald states (p. 41) little was altered in terms of the degrees of affinity and their observance between the Fourth Lateran Council of 1215 and the sixteenth century, when new laws were devised by the Council of Trent for Catholic Europe and Henry VIII for Protestant England.
} 
text. ${ }^{9}$ She does not reflect further on this, but in her remark lies the key to the remanieur's process of dealing with the ethical and interpretative problem thrown up by the earlier text. The Burgundian author adopts and adapts the personification, an apparently stock literary device common to many late-medieval texts - and, further, one derived from his source -, and develops out of it a sustained and sustainable hermeneutic strategy. Far from being isolated, allegorising examples of a personified agent interacting with a character in the text, the abstract notions in the prose Cligès permit, as Colombo Timelli suggests, those characters' emotions to be systematically exteriorized; and they become thereby inflected with exegetical and ideological meaning on a textual and extra-textual level. In what follows I discuss the ways in which this subtle narrative strategy is set up, how the abstraction of Amours is used in support of Alixandre and Soredamours's love in the first section of the text, before examining how it is developed in the second half to answer the ideological challenge posed by the endogamous relationship between Cligès and Fenice.

In the first part of the Cligès, no external barrier is presented to the potential union of Alixandre and Soredamours ; rather, any hindrance posed comes from the characters themselves, and in particular Soredamours. Her resistance to and disdain for love are described at her and Alixandre's first meeting, as they sail to Brittany with Arthur and Guinevere. This description is accompanied in the prose version by an early indication of the remanieur's narrative strategy and its deployment : «celle qui ne daigna oncques amer chevalier ny escuier tant fust preu ne hardi au jour d'ui par une nouvelle mutacion sera convaincu et soubmise au lachs d'Amours » (p. 72). The past participles are revelatory: the Soredamours of the prose, unlike her verse predecessor, is «persuaded », « held in thrall by », the personified agent Amours. ${ }^{10}$ As her eyes are drawn almost despite themselves towards Alixandre, whom she cannot but rank as the most beautiful man she has ever seen,

le fiert Amourz de la saiette ferree d'or, voire au millieu du cuer, et au navrer elle mue couleur par pluseurz façons, et nullement tenir ne se peult de regarder Alixandre, dont elle achata a ung seul coup les reffus qu'elle a fait de pluseurz noblez hommes. Le ruide entendement de ceste damoiselle, naguerez obstiné en indignacion envers lez hommes, par ung ray soudein des vertus d'Amours est corrompu et rendu serf a remirer la beaulté d'Alixandre. Si devés savoir qu'au desracinement de ceste malditte obstinacion que Soredamours avoit envers lez nobles, qu'il convenoit bien a Amours monstrer patentement ses vertus comme il fist. (p. 72-3 ; emphasis added)

The apparently stock motif of Cupid's arrow piercing the heart of an unsuspecting victim assumes a new, and deeper, significance here. What matters is not so much the arrow's passage «voire au milieu du cuer», but the fact that Amours acti-

\footnotetext{
${ }^{9}$ Colombo Timelli returns to this notion, in connection with the personification of 'Dieu', in «Talanz li prant que il s'an aille (Cligés, v. 5056): d'un vers de Chrétien de Troyes à l'invention d'un prosateur de $\mathrm{XV}^{\mathrm{e}}$ siècle ", in Favola, mito, e altri saggi. Studi di letteratura e filologia in onore di Gianni Mombello (Allessandria : Edizioni dell'Orso, 2004), p. 359-75.

${ }^{10}$ This phrase can be read as including the personified Amours - a fact not immediately apparent - because of its proximity with the next sentence in which the agent's rôle is clear.
} 
vely and intentionally shoots it; and this illustrates the personification's syntactic function and the fact that on some levels it owes its personification to the arrow. This arrow hits Soredamours; it acts on her «ruide entendement» which becomes spellbound by Amours; and this happens through no volition on the part of Soredamours. She has been the passive «victim» of an outside agent; and though she tries to fight it with the help of similar personifications, she is weakened. Her confusion is palpable :

Car, nonobstant que son cuer fust enrudi et resistant aux vouloirs de Nature, commandemens et semoncez d'Amours, voire et a Raison, attendu qu'elle cuidoit nul homme estre suffisant pour parvenir a sa bonne grace, toutesvoies en soubit par ce ray qui descendi du soleil estant ou ciel d'Amours, d'autant qu'elle estoit rebelle et non daignant personne amer, d'aultretel et plus fust elle engrant d'amer. (p. 73)

As the italicised sections in the above two quotations underline, Soredamours' previous state, her "obstinacion», was something controlled by and contained within her; her disdain was a conscious, active reaction, unlike this passive bending to the offices of Amours. From being defiantly «rebelle», Soredamours has been made «engrant» to love through an innovative expedient vital to the remanieur's overall narrative strategy. The external nature of Amours' influence is intensified by being itself mediated.

Of course, the attentive reader of Chrétien might dispute any such claims to the originality of this device's use in the prose reworking. After all, this same potshot is taken in the twelfth-century source, for apparently the same reasons :

Et la reine voirement

I amena Soredamors

Qui desdaigneuse estoit d'amors :

Oncques n'avoit oï parler

D'ome qu'ele daignast amer,

Tant eüst beauté, ne proesce,

Ne seignorie, ne hautesce.

Et ne por quant la dameisele

Estoit tant advenant et bele

Que bien deüst d'amors aprandre,

Se li pleüst a ce antandre ;

Mes oncques n'i volt metre antante.

Or la fera Amors dolante.

Et molt se cuide bien vangier

Del grant orguel et del dangier

Qu'ele li a toz jorz mené.

Bien a Amors droit assené :

El cuer l'a de son dart ferue 
Sovant palist sovant tressue,

Et maugré suen amer l'estuet. ${ }^{11}$

It might seem that Chrétien is conveying the same information as the Burgundian author, and this is broadly true : the same facts are laid out - Soredamours has never found a man whom she would deign to love, Cupid takes charge of matters and shoots an arrow, and she consequently loves despite herself -, certainly, but the method through which the information is presented differs significantly from author to author. These differences centre on the personification of Amours.

A useful distinction to draw between the two versions in this respect is the one developed by James J. Paxson. Paxson terms «first personification» local rhetorical ornament at the level, strictly, of discourse, while «second personification» designates a personified figure operating at the level of story and existing on the same ontological plane as the characters with whom it interacts. ${ }^{12}$ According to this terminology, the figure of Amours in the mise en prose can clearly be read as second personification: it takes on the rôle of an actor in the drama, working in similar ways to the characters whose destinies it moulds. It assumes thereby an active function that is absent from the localised usage of Amors in Chrétien's text. While it might be tempting to see this latter figure as an earlier example of a second personification acting at the level of story, the implication of Chrétien's Amors is that of a first personification, for it operates, punctually, in a conventionally Ovidian - and therefore rhetorical or ornamental - sense, to represent the stock notion of Cupid's intervention. It lacks, in other words, the positive agency of Amours in the mise en prose. This is illustrated in the case of Soredamour's emotions being externalised by the remanieur's suggestion that Amours acts on her faculty of understanding («entendement»), at a further and important remove from the conventional figure in Chrétien : this greatly accentuates the passive yielding of Soredamours to the authority of Amours, and the concomitant function of the personification as decisive, external agent in the Burgundian author's normalising hermeneutic strategy. Amours' actions, viewed in this regard, neatly explain Soredamours' volte-face while also contributing to the systematic accretion of such interventions which will, as shown below, ultimately delete the alterity of Cligès and Fenice's relationship.

What the remanieur is attempting in his reworking of the earlier poem is to present the love between Soredamours and Alixandre as right, and as externally countenanced : this is underlined by his stressing, through further uses of the personified agent, the parity between the two, their having been «made for each other». The same thing happens to Alixandre as happened to Soredamours : he is ineluctably drawn to looking at her and reflecting on her beauty, and as he does so, «Amours le fiert». But Amours does not in this instance stop there, and «lui commence a faire [ung] advertissement», telling Alixandre that it seems to him (the personification) that he would be very happy with Soredamours, who is «belle» just as Alixandre is

${ }^{11}$ Les Romans de Chrétien de Troyes. II Cligès, publié par A. Micha, Paris, 1975, v. 435-57, p. 14-15. Emphasis added. Subsequent references will appear in the text.

${ }^{12}$ The Poetics of Personification, Cambridge, 1994, p. 161. 
«bel». This discourse from Amours prompts Alixandre to express his feelings for Soredamours and about the love he experiences :

Il eslieve son cuer a remirer la courtoisie de ceste tant gente pucelle, et ne cesse de fonder soupirs et sangloux correspondans a ceulx de celle qui l'ayme. Moult est ceste amour lealle et naissant d'une vraie fondacion et lumiere amoureuse. (p. 73-4)

This final narratorial comment on Alixandre's emotion is derived by the prosateur directly from Chrétien's «ceste amors est leax et droite» (v. 528), thereby underlining his use, and development, of the authority of the source on the fitness of this relationship as he does with the personification of Amours. Within this, too, something more interesting is going on: if the personified agent of Amours can speak and persuade a character of something through voice, as well as through action as in the case of Soredamours, then this is evidence of a much more subtle narrative strategy than either the one seen in Chrétien or indeed that used in connection with Soredamours, where the personification acted but did not speak. Amours, in other words, explicitly makes the point that the couple are ideal partners through his comments on their parity; the narrator - the remanieur - interprets the verse source but again moves beyond it, shifting responsibility for the countenancing of the lovers' actions from himself to the external agent. This is another level in his strategy of a «deletion of alterity» in the prose which is being set up now in order to be given fuller import in the later section of the reworking.

Further evidence of Alixandre and Soredamours's similarity and fitness for one another comes when we are told that both are assailed by happiness and doubt in equal measure during the day, and that during the night they are both victim to "ymaginacions diverses et pencees melancolieuses», explicitly because of what Amours has done to them, as illustrated by their respective speeches. First comes Alixandre who reflects on his lovesickness as an intractable ailment, or rather one for which there is but one antidote that can only come from one source, a homeopathic application of the very germ that caused it. He cannot himself administer this ; he must wait to be acted upon as he was previously. Casting himself in the rôle of passive victim, as the italicised sections of the quotation show, he bewails this imprisonment and wonders how it came to be that he was caught so unawares :

...[P]our ce seul regard j'eusse esté enserré en ceste paine dolloureuse.... Et cuide bien moy que je feroie grant sens se plus a elle ne penssoie, si ne sçay comment je puisse faire, car Amours espoir me veult chastier et monster [sic] sa puissance sur moy..., et cuide bien moy que Amours qui est juste juge, aprés ceste griefve souffrance aydera a consoler mon cuer qu'il a trespercié de son dart. (p. 76)

His state of confusion is such that he cannot seem to decide whether Amours is cruel or just ; and he only adds to this confusion when he comes to reflect - as did Chrétien's Alixandre - on the logic of what befell him when the arrow struck him. How, he wonders, did it pierce him ? It can't have gone through his eye, for if it had it would have damaged the organ, which remains «net et sain»; so he would love to know how «Amours m'a en mon coeur si trescruellement navré » (p. 77) without leaving a mark on his body. The verse Alixandre spends some three hundred lines 
debating this physiological curiosity with himself, while the prosateur finds a means of dealing with this lengthy poetic debate, in which he can both creatively turn the authority of the verse source to considerable, novel, account and expand his thesis on the rightness of love. Alixandre is visited by another garrulous personified abstraction not present in Chrétien, this time of Enseignement :

\begin{abstract}
Mon beau fils, qui enquiers comment Amours te puisse avoir feru au cuer, saces que ses euvres sont si soubtilles qu'elles ne sont pas a asavourer magnifestement du premier coup, et sachiés que, lorsque premierement tu gectas tes yeulx pour voir Soredamours et elle te samblat belle, lors Amours te regarda de son haultain siege imperial et par le milieu de ta pencee getta sa saiette, qui dedens ton cuer entra sans blecier le corps, comme le soleil passe parmi la verriere sans le casser. (p. 77)
\end{abstract}

Through Enseignement's explication of the subtext to Chrétien's verse narrative (v. 618-864), Alixandre is given several pieces of information useful both to him and to a fuller understanding of the Burgundian author's ways of reading his Champenois source. Amours is a higher authority than any human; and he works mysteriously but in ways that are considered right by and for that human. He saw Alixandre looking at Soredamours, and because it was the right thing to do, sealed the lovers' fate with an arrow.

The rightness of the love, and the notion that logic is a futile weapon to use against it, is underlined by Soredamour's parallel monologue. She realises, like Alixandre, that she has not, and cannot have, any power over what she feels,

car, nonobstant que je me veulle reposer et cesser de pencer a lui, ce ne me vault, car Amours m'a trop asprement envahie, et convient que je amodere mon corage et que je obtempere aux soudains commandements d'Amours, ausquels j'ay longuement contredit et resisté que plus faire ne puis. Il me convient faire ce qu'Amours m'annonce (p. 78)

She refers explicitly to changes that «Amour veult» that she effect on her character, that she swap her pride and hot-headedness for loyalty and obedience, and moreover is happy to do this, for «Raison me denonce que il me convient une fois acquitier envers Amours ». Indeed, Soredamours is so enthralled by Amours, and by the notion of love, that she appeals gladly to another level of predestination, a rather obvious one that she has not, however, seen (or been in a position to see) previously : « $[\mathrm{J}] \mathrm{e}$ ferai ce que mon nom m'enseigne. Car 'sore' vault autant dire comme couleur de l'or, qui plus est sor et plus est affiné, et l'autre partie 'damours' avec ce premier mot 'sore' doit estre dit 'sororee d'amours', c'est a dire la plus especialle qui jamés fut touçant les fais d'amours » (p. 78). The remanieur again appropriates the definition given by Chrétien's Soredamours (v. 954-979) and uses it in support of his own exegesis, of the new coherences he wishes to forge in his reworking. Through this strategy the remanieur establishes in creative ways an Ars Amatoria functioning on the assumption that right love is externally driven and externally countenanced, and permitting the neat refocusing of the ideological challenge presented in the source by Cligès and Fenice's relationship. In what follows I examine 
the full import of this exegetical strategy deployed in the first half of the text with reference to the second, more troubling, section of the Cligès.

In this second section of the Cligès there are in fact two relationships to consider, not only the potentially problematic union between aunt and nephew, but also the disturbingly-presented marriage of Fenice and Alix. When the former is read against the latter, through the lens of the legitimate love described in the first section, the value of this narrative strategy as a normalizing device becomes the clearer. In order to indicate the moral value attributed to Fenice and Alix's marriage in contrast with that of Fenice and Cligès the remanieur adopts the very significant strategy of, precisely, not adopting his strategy: the personified agent of Amours plays no smoothing, legitimising rôle in this union as it will later in the section. The early stages of the relationship between Fenice and Alix are presented in mercantile, hierarchical terms, as an expedient political measure rather than as something inherently to be desired, and in this it contrasts sharply with the later aunt-nephew strand. Alix decides that he would like to be married to Fenice before having seen her, because he is assured that she is «belle a droit entre cent mille» (p. 103). In order to achieve this aim he need only petition her father and contract an agreement with him : Fenice, in other words, is not asked her opinion on the matter. On this very basic level the discord between the parties when read through the view of love presented in connection with Alixandre and Soredamours and the perfect equipoise between their respective sentiments ought to give us pause for thought; and this is compounded in the fact that nowhere are the actions or emotions of Alix, nor indeed of Fenice, countenanced by the personified agent Amours. ${ }^{13}$

Both these aspects, the disjunction between bride and groom, and the absence of the legitimising abstract agent, stand in stark and deliberate contrast with what the remanieur does in the latter part of his second section. From the first meeting of Cligès and Fenice he is at pains to stress their parity, and concomitantly, as with Alixandre and Soredamours, the rightness of what they feel for one another. Their parity, indeed, is communicated as a function of their disparity with other people. In the case of Fenice, like that of Soredamours, this is expressed in her name :

\footnotetext{
${ }^{13}$ Two further comments can be adduced in support of this point. Firstly, Fenice and Alix are not only unevenly matched politically, they are also- unlike Cligès and Fenice, and Alixandre and Soredamours - physically disparate : while Fenice is habitually described as «pucelle» or «demoiselle», Alix is 'le viellart de Constantinople'. Secondly, the remanieur's conviction of the illegitimacy of Fenice and Alix's relationship is stressed in a small but telling deviation from the authority of Chrétien's text. Fenice is reluctant to consummate her union with Alix after the wedding ceremony, so her nurse Thessala brews a potion that will hoodwink the groom into thinking that consummation has taken place. Under the influence of the potion, Alix does what his verse predecessor does not and subjects his new wife to an oneiric rape: "[il] lui samble qu'elle ne veult baisier n'acoller comme ne font les aultres pucelles la premiere nuit qu'elles coucent avec leurz maris, més aux conclusions il lui samble qu'elle s'acorde autant par amour que par force » (p. 115). In Chrétien's text, by contrast, the emperor «neant tient, et neant beise,/Neant tient, et neant acole,/A neant tance, neant luite [...]/De neant est an si grant paine,/Car par voir cuide, et si s'an prise,/Qu'il ait la forteresce prise $»($ v. 3318-3326).
} 
Le nom de la pucelle ne lui mentoit pas : elle estoit nonmee Fenice, et ainsi que le fenix, qui est seul oiseau de son plumage impareil a toux aultres, pareillement est il de la damoiselle. Car elle est la plus de plus, sans per et sans ce que nul aultre dame soit digne d'estre comparee a la tierce parti de sa haultaine beaulté. Et, au vray dire, chascun disoit qu'il n'estoit possible a Nature, nonobstant qu'elle soit soubtille, qu'elle sceust advenir a composer de toutes choses ung chief d'euvre pareil ad ceste. (p. 104-5)

This last remark of the remanieur's is in fact susceptible of some modification, for Nature has indeed shaped a work «pareil ad ceste»: this is Cligès, who is described in startlingly similar terms to those used in connection with Fenice. After the enumeration of his fine physical qualities, it is revealed that « estoit il tant bien tourné que Nature en ung million d'honmes ne sauroit advenir a en faire ung de telle fourme, n'estoit par la permission de Dieu a cui rien n'est impossible' (105). In these few lines the moral and ideological stage is set as it was in the first section, and soon a familiar actor makes his entrance.

As Fenice is brought before her father and Alix, in the presence of the latter's nephew, 'Cligès, qui la voit en ceste honneur, ne se peult contregarder qu'il ne faille que Amours vertisse et tourne ses yeulx vers elle» (p. 105). As previously, in the case of Alixandre and Soredamours, the lover's eye cannot be drawn from the object of his affections; and, again as previously, the same thing happens to the woman as to the man («et elle pareillement envers Cligès»). The personified agent Amours acts physically and unbidden on the unsuspecting victims, as illustrated by the active verbs in the binomial «vertisse et tourne » (the sense is very different in Chrétien's «Mes Clygés par amors conduit/Vers li sez ialz couvertement» (v. 2760-1), which centres on Cligès's own volition, and where the «amor» mentioned is simply the emotion and not the personification of it), and a few lines later by the fact that «Amours fait leurz deux pencees convenir en ung seul et arresté desir, et ... qu'ilz soient attains des trais d'Amours egalement et a juste mesure» (p. 106). Equality and ineluctability are the dominant characteristics of their nascent relationship ; and the remanieur continues to take pains to convince the reader of this, of the powerlessness of Cligès and Fenice when faced with this headstrong outside agent, when stating that on another occasion Cligès looks at Fenice «par l'enhortement d'Amours »(p. 110), and later having Thessala remark pertinently to Fenice that «il n'est chose plus certaine que Amours vous tient a son service» (p. 111).

Two further episodes of the personified agent being used to «projeter à l'extérieur les sentiments mêmes des personnages» should be adduced here. Both centre, as did the previous ones, on the legitimacy of the love between Fenice and Cligés, but allow more comment to be made on why the prosateur might want to focus so strenuously on this in his rewriting of Chrétien's poem. The first of these episodes is apparently minor, but casts significant light on what follows. After he has dealt so successfully with the duke of Saxony (who attempted to abduct Fenice, p. 116-25), long-dormant chivalric ambitions are awakened in Cligès and he heads to Britain - with Fenice's blessing - and the court of Arthur. There he participates in many tournaments, vanquishing heroes such as Perceval, Lancelot, and his maternal uncle Gauvain. While jousting against this last he thinks of Fenice; the thought spurs him on to enough renewed vigour to allow him to beat Gauvain as he did not 
in Chrétien (there they are so evenly matched there that Arthur cannot say «quiex ert miaudres, ni li quiex pire», v. 4902). The confluence of this serendipitous thought and the sole episode of the prose Cligès with no foundation in Chrétien - the meeting between Cligès and a weeping damsel - have led critics, and notably Maria Colombo Timelli, to see this episode as a «simple instance narrative, à la fonction de déclencheur d'une nouvelle action, le départ du protagoniste $»{ }^{14}$ But far from being a simple plot device, this added episode functions as part of the Burgundian author's method of responding to and normalizing the ideological challenge underscored by Cligès and Fenice's union.

As the damsel bewails her sorry amorous lot, she speaks in terms that recall earlier episodes in the text and which allow attention to be projected towards later aspects of the story in respect of the legitimacy of the aunt-nephew relationship. Firstly, the knight whom the damsel loves and whom she does not name is, she fears, lost to her, for her father wanted to marry her to someone else ; and this, which crucially recalls Fenice's situation, is why she has escaped. While she weeps, she combs her "chevellure belle et blonde», an echo of the shirt Soredamours wove with her hair and with gold for Cligès's father, whose acceptance and comprehension of the item (p. 80-1; p. 84-5) underscores the validity of his love for Soredamours. After he has heard her story, Cligès pronounces her «lealle en Amours », which in its turn harks back to the narratorial comment above that « moult est ceste amour lealle», and stresses thereby the rightness of the damsel's sentiments. These three things - the damsel's plight, the echo of Soredamours in her blonde hair, and the « leal » aspect of the love -, when read alongside and through Cligès's decision to return to Constantinople, function as further evidence of the legitimacy of what he is returning to. As Cligès himself says,

le pleur de ceste damoiselle est digne de grant merite, voire et d'ausi grant guerredon qu'est le pleur d'un homme leal en ce service d'Amourz. Ad ce qu'elle a proposé d'avoir cité son ami par son doulx regard, je puis entendre que Fenice par ses yeulx m’a appellé a son amour (p. 136).

The added episode is less call to arms for Cligès than confirmation.

Upon his return to Constantinople, Cligès and Fenice meet and, in ways that stridently recall the depiction of Soredamours and Alixandre's relationship in the first half, evaluate the nature of what they feel for each other :

et Dieu merci, puisque vous avéz conffessé que vostre cuer a tous jourz avec moy esté, je puis bien dire qu'il est mien, et du mien puéz ausi jugier qu'il est plus que vostre, par lez soudains et bonnes acointances dont Amourz lez a annexes et tellement addonnéz ensambre que le mien est a vous et le vostre a moy (p. 139),

and discuss the means by which they will get out of their predicament in which they find themselves (unshakably in love with one another but with Fenice bound in marriage to Alix). Cligès sees it as a matter of some urgency that they do this, and

${ }^{14}$ Colombo Timelli, «Talanz li prant que il s'an aille ». 
underlines a further level of rightness in their union : not only has the personified agent of Amours countenanced it, but the supreme arbiter is also invoked in support of it : «Il plaist Dieu et Amourz que lealle acquaintance soit secretement et fermement entretenue» (p. 140). This is an especially important point for the remanieur's process of deleting the potential alterity of this relationship, for not only is it outside the control of its victims, it is desired not by them but by higher authorities (and is by implication freed of any immoral valency through receiving the approval of God, traditionally the «iustus iudex » just as previously Amours was described as «juste juge»). This is underlined when Fenice implements her plan to allow herself and Cligès to be together, and pretends to be dead (having drunk a «breuvage » made by Thessala). Alix is in mourning for her when some doctors from Salerno passing through Constantinople offer to take a look at her. They very quickly see that she is feigning death, and attempt to jolt her out of it with torturous trials recalling those common in female martyr narratives : they whip her and pour molten lead into her palms to impel her, precisely as in martyr narratives, to speech. But in Fenice's case speech comes there none, for «Amourz les gardera de faire parler la dame» (p. $151)$; «elle a en son ayde Amours» (p. 151) to such a degree that her ruse goes unproven, and she and Cligès can elope to the tower Cligès has had built. ${ }^{15}$

What is especially pertinent in this last example is the way in which the personified agent of Amours - and by extension the appeal to the ultimate authority of God - lends its support to what amounts to morally-reprehensible behaviour on the part of Cligès and Fenice. It acts in defence of Fenice as she deceives her husband here as she did previously; it permits Cligès to do what the Duke of Saxony was hounded for earlier in abducting Fenice from Alix ; and it allows Fenice to remain mute, to enact a lie, in the face of the Salternian medics' taunts, all of which seems exceedingly unsettling. But what needs to be borne in mind here is that these episodes have their roots, and hence their foundational dubiousness, in Chrétien's text, and are not the responsibility of the Burgundian author: what he must do in the production of the mise en prose is respond to the prior authority of the avatar, and make his reworking of it as palatable as possible for the new audience for whom he writes. The rôle of the remanieur is much less about the excision of episodes from the source-text in the production of the mise en prose than the appropriate levelling of features already contained in that source. So in this instance in the prose Cligès, the remanieur is working with the raw materials presented to him in Chrétien's poem and developing a means of containing and contending with them : because the incestuous union between Cligès and Fenice is present in the source it remains in the reworking, but cannot be allowed to stand without gloss. The ideological challenge for the remanieur is to convince his readership of the rightness of this union, and to smooth over its potential alterity. This he is able to do through the subtle hermeneutic strategy involving Amours.

The device of the personified agent is constructed in the first half of the prose Cligès through the authority of Chrétien's textual practice in his writing of the relationship between Alixandre and Soredamours. Through this device, used in connec-

${ }^{15}$ On this tower, and the particular acculturation-strategies of its building, see Taylor, «The Significance of the Insignificant ». 
tion with a morally-untainted pairing, the remanieur is able to develop a thesis on love pertinent to his reworking, one which focuses attention on a legitimate love and which suggests the externally driven nature of such legitimacy. Responsibility for the nascent love between Soredamours and Alixandre is laid not with the characters themselves, but squarely with the higher authority of Amours. And using Amours as the legitimising factor in this innocent union means that when the personified agent makes its appearance in the second half of the text, in connection with the ideologically challenging aunt-nephew relationship, immediately the implication is that this pairing should be viewed in the same light as the previous one. Amours in the first half of the text assumes a benevolent and morally upstanding valency which allows it later to fulfil an alterity-deleting function.

The remanieur supplies himself with a clear system to smooth over the perceived problem inherent in his source text, and a system which allows him, further, to abdicate authorial responsibility for the writing of such ideologically troubling events : the incestuous union came from Chrétien and must remain in the reworking, but its presence here is countenanced not by the remanieur himself but by Amours. In bringing this external authority to bear on his book, the Burgundian author ensures for his text not only the happy ending denied it in Chrétien (in the prose Fenice and Cligès marry) but, presumably, a happy ending and favourable reception at court. ${ }^{16}$ (Quite why incest should have been implicitly more problematic for the Burgundian court audience than it might have been for Chrétien's readership is difficult to adduce with any certainty, though might be due to the vexed dynastic questions never far from Philip the Good's mind, and to the importance of maintaining the Burgundian blood-line. $)^{17}$ Far from having an «engin non suffisant», then, the remanieur assumes a subtle and suggestive narrative strategy to overcome a large ethical question posed for him by his verse avatar, reading through and interpreting the authority of this work to promote new coherences for his target audience, and exhibiting, conversely, considerable 'bon sens et engin'. The wedding-reception staged by the author of the prose Cligès underlines one way in which the full import of a text is not lost, but found, in translation.

Rebecca Dixon University of Manchester

\footnotetext{
${ }^{16}$ Charity Cannon Willard suggests that the fact that the prose Cligès has come down to us in a «single manuscript written on paper in an undistinguished hand», held as Leipzig Universitätsbibliothek, Rep.II.108, indicates that its reception at court was in fact unfavourable. No contemporary documentary evidence exists to prove or disprove this hypothesis. See «The Misfortunes of Cligès at the Court of Burgundy », in Arturus Rex. Acta Conventus Lovaniensis, 2 vols., ed. W. van Hoecke, G. Tournoy, and W. Verbeke, Leuven 1991, vol. 2, p. 397-403. This remark is on p. 399.

${ }^{17}$ Philip the Good sired three (legitimate) sons, but only the last, the future Charles the Bold, survived to adulthood. On this see R. Vaughan, The Dukes of Burgundy. Philip the Good, Woodbridge, 2002.
} 